\title{
Penelitian Pengaruh bermain meniup balon (Balloon therapy) TERHADAP STATUS OKSIGENASI ANAK USIA 3-5 TAHUN DENGAN PNEUMONIA DI RUMAH SAKIT TK.II PELAMONIA Alfin Nugroho, ${ }^{1}$ Indra Dewi, ${ }^{1}$ Arham Alam, ${ }^{2}$ \\ ${ }^{1}$ STIKES Nani Hasanuddin Makassar \\ ${ }^{2}$ Kantor Kesehatan Pelabuhan Kelas 1 Makassar
}

\begin{abstract}
ABSTRAK
Pendahuluan: Pneumonia adalah radang akut yang menyerang jaringan paru dan sekitarnya yang dapat berdampak pada status oksigenasi khususnya pada anak. Tujuan penelitian ini untuk mengetahui Pengaruh Bermain Meniup Balon (Balloon Therapy) Terhadap Status Oksigenasi Anak Usia 3-5 Tahun Dengan Pneumonia Di Rumah Sakit Tk.II Pelamonia tahun 2018.

Metode: Penelitian ini menggunakan jenis penelitian Pra-eksperimen dengan rancangan penelitian One group pre test and post test design dengan jumlah sampel 22 sampel. Teknik sampling yang digunakan adalah purposive sampling.

Hasil: Hasil analisis bivariat didapatkan ada pengaruh sebelum dan sesudah diberikan aplikasi kegiatan bermain meniup balon (balloon therapy) terhadap status oksigenasi Heart Rate (HR) dan Saturasi Oksigen $\left(\mathrm{SaO}_{2}\right)$ dengan masing-masing nilai $\rho$ Value 0,000. Namun tidak terdapat perbedaan signifikan yang ditemukan pada tingkat Respiratory Rate (RR) nilai $\rho$ Value 0,124.
\end{abstract}

Kesimpulan: Hasil penelitian ini diharapkan dapat diterapkan dalam memberikan asuhan keperawatan pada anak yang mengalami gangguan status oksigenasi dengan menggunakan pendekatan atraumatic care.

Kata kunci : Pneumonia, Status Oksigenasi, Bermain Meniup Balon.

\begin{abstract}
Introduction: Pneumonia is an acute inflammation that attacks the lung and surrounding tissues which can affect oxygenation status especially in children. The purpose of this study is to know The Effect of Play Blowing Up Balloon (Balloon Therapy) to Oxygenation Status of 3-5 Years Old Children with Pneumonia in Pelamonia Level II Hospital at 2018.

Methods: This study using Pre-experimental study with one group pretest and posttest study design for 22 participants which recruited by purposive sampling method.

Result: The results of the bivariate analysis showed that there was influence before and after being given the application of play blowing up balloon activities (balloon therapy) to oxygenation status as Heart Rate (HR) and Oxygen Saturate (SaO2) with each $\rho$ Value 0.000. meanwhile there is not significantly different that showed in Respiratory Rate (RR) level with $\rho$ value 0.124 .

Conclusion:The results of this study are expected to be applied in providing nursing care for children who experience oxygenation status disorders using the atraumatic care approach.
\end{abstract}

Keywords: Pneumonia, Oxygen Status, Play Blowing Up balloon 


\section{PENDAHULUAN}

Pneumonia atau sering disebut paruparu basah adalah infeksi paru-paru yang ditandai batuk, demam, dan kesulitan bernafas (sesak). Penyakit ini disebabkan oleh bakteri atau virus dan merupakan penyakit yang dapat diobati. Berbeda dengan tuberculosis yang memerlukan pengobatan minimal 6 bulan, pneumonia hanya memerlukan pengobatan antara 5 hari hingga 2 minggu saja. Tetapi bila pengobatan terlambat maka sangat sering menyebabkan kematian ${ }^{[1]}$.

$\begin{array}{llr}\text { Bakteri penyebab pneumonia yang } \\ \text { tersering } & \text { adalah penumokokus } \\ \text { (Streptococcus } & \text { pneumonia), } \mathrm{HiB}\end{array}$
(Streptococcus pneumonia), HiB (Haemophilus influenza type b), dan stafilokokus (Staphylococcus aureus). Virus penyebab pneumonia sangat banyak, misalnya rhinovirus, respiratory syncytial virus (RSV) atau virus influenza. Virus campak (morbili) juga dapat menyebabkan komplikasi berupa pneumoni ${ }^{[2]}$.

WHO menyebutkan, pneumonia merupakan penyebab dari $15 \%$ kematian balita, yaitu diperkirakan sebanyak 922.000 balita di tahun $2015^{[3]}$. Secara global, tingkat kematian neonatal (probabilitas kematian pada 28 hari pertama kehidupan) menurun kurang cepat dibandingkan tingkat kematian anak-anak antara 1 bulan dan 5 tahun. Ini berarti bahwa jumlah kematian di bawah lima tahun yang terjadi selama periode neonatal semakin meningkat. Pada tahun 2015, kematian neonatal menyumbang $45 \%$ dari total kematian, $5 \%$ lebih banyak dari pada tahun $2000^{[4]}$.

Peningkatan jumlah kematian pada periode neonatal mencerminkan penurunan mortalitas anak-anak berusia 1 sampai 59 bulan di banding bayi yang baru lahir. Namun, dari 5,9 juta korban di bawah lima tahun pada 2015, hampir setengahnya disebabkan oleh penyakit menular dan kondisi seperti pneumonia, diare, malaria, meningitis, tetanus, campak, sepsis dan AlDS. Pneumonia dan diare tetap menjadi penyebab utama kematian di tiga wilayah dengan kematian di bawah lima tahun ${ }^{[4]}$. Salah satu upaya yang dilakukan untuk mengendalikan penyakit ini yaitu dengan meningkatkan penemuan pneumonia pada balita.

Berdasarkan hasil studi pendahuluan di ruang perawatan anak Rumah Sakit Tk.II Pelamonia, menyebutkan bahwa pada tahun 2016, ditemukan angka kejadian pneumonia pada anak sebanyak 457 kasus. Sedangkan pada tahun 2017 ditemukan angka kejadian pneumonia pada anak sebanyak 1.045 kasus. Ini berarti terjadi peningkatan secara signifikan kejadian pneumonia, yakni sebanyak 588 kasus pneumpnia di ruang perawatan anak di Rumah Sakit Tk.II Pelamonia.

Masalah keperawatan yang umumnya banyak ditemukan pada anak dengan pneumonia adalah masalah bersihan jalan nafas tidak efektif. Salah satu intervensi keperawatan yang dapat diberikan untuk mengatasi masalah tersebut adalah dengan Pursed Lips Breathing (PLB). Pursed Lips Breathing dapat meningkatkan ekspansi alveolus pada setiap lobus paru sehingga tekanan alveolus meningkat dan dapat mendorong secret pada jalan nafas saat ekspirasi. PLB bisa digunakan pada anak yang mau diajak bekerjasama. Namun sering kali anak sulit diajak bekerjasama untuk melakukan tehnik tersebut, hal tersebut bisa saja disebkan karena stress hospitalisasi. Untuk dapat menarik minat anak-anak, dibutuhkan modifikasi intervensi yaitu dengan kegiatan bermain meniup balon yang mekanismenya mirip dengan PLB dengan menggunakan pendekatan atraumatic care yaitu dengan bermain meniup balon. Berdasarkan uraian diatas peneliti tertarik untuk meneliti tentang pengaruh bermain meniup balon (balloon therapy) terhadap status oksigenasi anak usia 3-5 tahun dengan pneumonia di Rumah Sakit Tk.II Pelamonia.

\section{METODOLOGI PENELITIAN}

Desain, Waktu penelitian, populasi dan sampel

Penelitian ini dilakukan tanggal 04 Juni sampai dengan 04 Juli 2018 di Rumah Sakit Tk.II Pelamonia. Penelitian ini menggunakan jenis penelitian Pra-eksperimen dengan rancangan penelitian one group pre test and post test design.

Populasi adalah pasien anak dengan diagnosa penyakit pneumonia di rawat inap Rumah Sakit Tk.II Pelamonia yaitu sebanyak 22 orang. Teknik sampling yaitu teknik purposive sampling sesuai dengan kriteria inklusi.

\subsection{Kriteria Inklusi}

1 Anak usia 3-5 tahun (usia 36-60 Bulan)

2 Anak yang dirawat dengan pneumonia

3 Hari rawat ke-dua

4 Tingkat kesadaran Composmentis

5 Anak mampu diajak kerjasama

6 Orang tua bersedia menjadi mitra peneliti

\subsection{Kriteria Ekslusi}

1 Anak dengan pneumonia disertai penyakit lain seperti penyakit jantung, 
trauma atau konfigurasi struktur dada yang tidak normal

2 Sedang mendapatkan suplemen oksigen

3 Kondisi anak sangat lemah sehingga tidak mampu meniup balon

4 Orang tua tidak kooperatif dan tidak mau dijadikan mitra

\subsection{Langkah Pengelolahan Data}

1 Editing

Peneliti melakukan pemeriksaan terhadap data yang telah diperoleh dengan mengecek kembali isian pada lembar observasi apakah sudah lengkap, jelas, dan relevan.

2 Coding

Pada tahap ini peneliti melakukan pengkodena terhadap variabel penelitian, proses pemberian code oleh peneliti, setiap variabel untuk memperoleh peneliti dalam melakukan analisis data dan mempercepat pada saat memasukkan data.

3 Entri Data

Peneliti memproses data dengan memasukkan data dari masing-masing responden kedalam program komputer. Pada tahap ini yang dilakukan peneliti adalah memasukkan data dengan lengkap dan sesuai dengan coding dan tabulating ke dalam paket program komputer dengan tujuan untuk menganalisa sesuai tujuan penelitian.

\subsection{Analisa Data}

1 Analisis Univariat

Analisis univariat dilakukan untuk mendeskripsikan karakteristik masingmasing variabel yang diteliti atau untuk mengestimasi parameter populasi. Variabel yang dianalalisis yaitu usia dan jenis kelamin melalui uji analisis frekuensi..

2 Analisis Bivariat

Hasil penelitian ini terlebih dahulu dilakukan uji normalitas dari data yang didapatkan dengan menggunakan

Non-parametrik test yakni uji normalitas Kolmogrov Semirnov. Kemudian diuji secara statistik dengan uji paired t-test atau uji $\mathrm{t}$ berpasangan karena data yang diperoleh dari uji normalitas adalah berdistribusi normal sebaran normal
HASIL

3.1 Analisa Univariat

Tabel 1 Distribusi Frekuensi Berdasarkan Karakteristik Responden Di Rumah Sakit Tk.II Pelamonia $(\mathrm{n}=22)$.

\begin{tabular}{ccc}
\hline Karakteristik & $\mathrm{N}$ & $\%$ \\
\hline Golongan Umur & & \\
3 Tahun & 9 & 40,9 \\
4 Tahun & 7 & 31,8 \\
5 Tahun & 6 & 27,3 \\
\hline Jenis Kelamin & & \\
Laki-laki & 8 & 36,4 \\
Perempuan & 14 & 63,6 \\
\hline
\end{tabular}

\subsection{Analisa Bivariat}

Tabel 2 Distribusi HR, RR dan $\mathrm{SaO}_{2}$ Sebelum Bermain Meniup Balon (Ballon Therapy) Di Rumah Sakit Tk.II Pelamonia.

\begin{tabular}{|c|c|c|c|c|}
\hline Variabel & Mean & SD & $\begin{array}{l}\text { Minimal- } \\
\text { Maksimal }\end{array}$ & $95 \% \mathrm{Cl}$ \\
\hline $\begin{array}{l}\text { Hearth } \\
\text { Rate }(\mathrm{HR})\end{array}$ & 92,59 & 10,473 & $60-100$ & $\begin{array}{l}87,95- \\
97,23 \\
\end{array}$ \\
\hline $\begin{array}{l}\text { Respiratory } \\
\text { Rate (RR) }\end{array}$ & 27,09 & 2,022 & $24-30$ & $\begin{array}{l}26,19- \\
27,99\end{array}$ \\
\hline $\begin{array}{l}\text { Saturasi } \\
\text { Oksigen }\end{array}$ & 96,05 & 1,299 & $95-98$ & $\begin{array}{l}95,86- \\
96,69\end{array}$ \\
\hline
\end{tabular}

Berdasarkan tabel 5.4. Diperoleh hasil analisis Heart Rate (HR) responden sebelum bermain meniup balon (balloon therapy). sebesar $92,59 \mathrm{kali} /$ menit $(95 \% \mathrm{Cl}$ : 87,95-97,23), dengan standar deviasi 10,473. HR terendah responden sebesar $60 \mathrm{kali} / \mathrm{menit}$. Dari hasil estimasi interval dapat disimpulkan 95\%, bahwa rata-rata HR responden berdistribusi diantara 87,95 sampai dengan 97,23 kali/menit.

Hasil analisis Respiratory Rate (RR) responden sebelum bermain meniup balon (balloon therapy) sebesar 27,09 kali/menit $(95 \% \mathrm{Cl}: 26,19-27,99)$, dengan standar deviasi 2,022. RR terendah responden sebesar 24 kali/menit. Dari hasil estimasi interval dapat disimpulkan 95\%, bahwa rata-rata $R R$ responden berdistribusi diantara 26,19 sampai dengan 27,99 kali/menit.

Hasil analisis Saturasi Oksigen $\left(\mathrm{SaO}_{2}\right)$ responden sebelum bermain meniup balon (balloon therapy) sebesar $96,05 \%(95 \% \mathrm{Cl}$ : 95,86-96,69), dengan standar deviasi 1,290. SaO2 terendah responden sebesar $95 \%$. Dari hasil estimasi interval dapat disimpulkan 95\%,

bahwa rata-rata $\mathrm{SaO}_{2}$ responden berdistribusi diantara 95,86 sampai dengan $96,69 \%$ 
Tabel 3 Distribusi HR, RR dan $\mathrm{SaO}_{2}$ Sesudah Bermain Meniup Balon (Ballon Therapy) Di Rumah Sakit Tk.II Pelamonia

\begin{tabular}{|c|c|c|c|c|}
\hline Variabel & Mean & SD & $\begin{array}{l}\text { Minimal- } \\
\text { Maksimal }\end{array}$ & $95 \% \mathrm{Cl}$ \\
\hline Hearth & 101,1 & 9,79 & \multirow{2}{*}{$78-120$} & $96,79-$ \\
\hline Rate (HR) & 4 & 9 & & 105,48 \\
\hline Respirator & & & & \\
\hline $\begin{array}{l}\text { y Rate } \\
\text { (RR) }\end{array}$ & 26,00 & $\begin{array}{c}2,13 \\
8\end{array}$ & $22-28$ & $\begin{array}{l}25,05- \\
26,95\end{array}$ \\
\hline Saturasi & \multirow{2}{*}{97,77} & \multirow{2}{*}{528} & \multirow[b]{2}{*}{$97-99$} & $97,54-$ \\
\hline Oksigen & & & & 98,01 \\
\hline
\end{tabular}

Berdasarkan tabel 5.5. Diperoleh hasil analisis Heart Rate (HR) responden sesudah bermain meniup balon (balloon therapy) sebesar 101,14 kali/menit (95\% $\mathrm{Cl}: 96,79-105,48)$, dengan standar deviasi 9,799 . HR terendah responden sebesar 78 kali/menit. Dari hasil estimasi interval dapat disimpulkan 95\% diyakini bahwa rata-rata HR responden berdistribusi diantara 96,79 sampai dengan 105,48 kali/menit.

Hasil analisis Respiratory Rate (RR) responden setelah bermain meniup balon (balloon therapy) sebesar 26,00 kali/menit $(95 \% \mathrm{Cl}: 25,05-26,95)$, dengan standar deviasi 2,138. RR terendah responden sebesar $22 \mathrm{kali} / \mathrm{menit}$. Dari hasil estimasi interval dapat disimpulkan 95\% diyakini bahwa rata-rata RR responden berdistribusi diantara 25,05 sampai dengan 26,95 kali/menit.

Hasil analisis Saturasi Oksigen $\left(\mathrm{SaO}_{2}\right)$ responden setelah bermain meniup balon (balloon therapy) sebesar $97,77 \%(95 \% \mathrm{Cl}$ : 97,54-98,01), dengan standar deviasi 528. $\mathrm{SaO}_{2}$ terendah responden sebesar $97 \%$. Dari hasil estimasi interval dapat disimpulkan $95 \%$ diyakini bahwa rata-rata $\mathrm{SaO}_{2}$ responden berdistribusi diantara 97,54 sampai dengan $98,01 \%$.

Tabel 4 Distribusi HR, RR dan $\mathrm{SaO}_{2}$ Sebelum dan Sesudah Bermain Meniup Balon (Ballon Therapy) Di Rumah Sakit Tk.II Pelamonia

\begin{tabular}{lccc}
\hline \multicolumn{1}{c}{ Variabel } & Mean & SD & $P$ Value \\
\hline $\begin{array}{l}\text { Hearth Rate } \\
\text { (HR) }\end{array}$ & $-8,545$ & 8,601 & 0,000 \\
\hline $\begin{array}{l}\text { Respiratory } \\
\text { Rate (RR) }\end{array}$ & 1,091 & 3,191 & 0,124 \\
\hline $\begin{array}{l}\text { Saturasi } \\
\text { Oksigen }\end{array}$ & $-1,727$ & 1,241 & 0,000 \\
\hline
\end{tabular}

Berdasarkan Tabel 5.6 diatas, memberikan gambaran status oksigenasi sebelum dan sesudah bermain meniup balon (balloon therapy). Diperoleh nilai mean perbedaan dari Heart Rate (HR) sebesar $-8,545 \mathrm{kali} / \mathrm{menit}$ dengan standar deviasi 8,601 kali/menit. Analisis lebih lanjut menunjukkan rata-rata $\mathrm{HR}$ sebelum intervensi lebih tinggi dibandingkan dengan sesudah diberikan aplikasi kegiatan bermain meniup balon (balloon therapy) ( $\rho$ Value $=0,000, a=<0,05)$. Nilai mean perbedaan Respiratory Rate (RR) anak usia 3-5 tahun sebelum dan sesudah intervensi adalah sebesar 1,091 dengan standar deviasi 3,191 kali/menit. Analisis lebih lanjut menunjukkan rata-rata $R R$ setelah intervensi lebih tinggi dibandingkan dengan sesudah diberikan aplikasi kegiatan bermain meniup balon (balloon therapy) $(\rho$ Value $=>0,124, \alpha=0,05)$.

Nilai mean perbedaan Saturasi Oksigen $\left(\mathrm{SaO}_{2}\right)$ anak usia 3-5 tahun sebelum dan sesudah intervensi adalah sebesar $-1,727 \%$ dengan standard deviasi $1,241 \%$. Analisis lebih lanjut menunjukkan rata-rata saturasi oksigen setelah intervensi lebih tinggi dibandingkan dengan sebelum diberikan kegiatan bermain meniup balon (balloon therapy) ( $\rho$ Value $=$ $0,000, \alpha=<0,05)$.

\section{PEMBAHASAN}

\subsection{Karakteristik Responden}

Penelitian ini menggunakan kegiatan bermain meniup balon (balloon therapy). Merupakan intervensi yang menggunakan pendekatan atraumatic care. Intervensi ini merupakan analogi dari latihan nafas dalam yakni Pursed Lips Breathing (PLB) yang dapat meningkatkan inspirasi dan ekspirasi.

Hasil uji statistik pada HR sebelum dan sesudah intervensi terjadi pengaruh yang signifikan HR sebelum dan sesudah diberikan kegiatan bermain meniup balon (balloon therapy) di Rumah Sakit Tk.II Pelamonia. Perbedaan terjadi pada hasil uji statistik pada RR sebelum dan sesudah intervensi yaitu tidak terjadi pengaruh yang signifikan sebelum dan sesudah diberikan kegiatan bermain meniup balon (balloon therapy). Sedangkan hasil dari uji statistik dari $\mathrm{SaO} 2$ sebelum dan sesudah intervensi terjadi pengaruh yang signifikan $\mathrm{SaO}_{2}$ sebelum dan sesudah diberikan kegiatan bermain meniup balon (balloon therapy) di Rumah Sakit Tk.II Pelamonia.

Interprestasi hasil penelitian dijelaskan sesuai dengan tujuan penelitian dan hipotesis yang diajukan dalam penelitian ini yaitu diketahuinya pengaruh kegiatan bermain meniup balon (balloon therapy) terhadap status oksigenasi (HR, $\mathrm{RR}$ dan $\mathrm{SaO}_{2}$ ) pada anak usia 3-5 tahun dengan pneumonia di Rumah Sakit Tk.II Pelamonia. Teknik pengambilan sampel 
pada penelitian ini adalah Purposive Sampling yang telah sesuai dengan kriteria inklusi dan eksklusi yang ditetapkan oleh peneliti.

Jumlah responden dalam penelitian ini adalah berjumlah 22 orang anak usia 3660 bulan. Hasil temuan responden Laki-laki lebih sedikit dibandingkan dengan

responden yang berjenis kelamin Perempuan yang diberikan intervensi kegiatan bermain meniup balon (balloon therapy) yang diperoleh dari ruang perawatan anak (Dahliah) Rumah Sakit Tk.Il Pelamonia. Hal tersebut bisa terjadi karena dipengaruhi volume pernafasan dan kapasitas vital yang meningkat. Volume dan kapasitas lebih besar pada anak laki-laki dibandingkan anak perempuan, yang dapat dihubungkan dengan peningkatan ukuran dada dan bahu pada anak laki-laki.

Hasil penelitian yang dilakukan peneliti melalui hasil observasi pengukuran status oksigenasi berupa Heart Rate (HR), Respiratory Rate (RR) dan Saturasi Oksigen $\left(\mathrm{SaO}_{2}\right)$ sebelum dan sesudah perlakuan (Intervensi), terdapat responden yang menunjukkan perubahan hasil pengukuran yang mengalami peningkatan dan penurunan (status oksigenasi) maupun hasil yang menetap, sebelum dan sesudah dilakukan kegiatan bermain meniup balon (balloon therapy).

\subsection{Bermain Meniup Balon (Balloon Therapy)}

Hasil pengukuran status oksigenasi Heart Rate (HR) dengan menggunakan alat Pulse Oksimeri diperoleh hasil observasi pengukuran, sebanyak 18 responden yang memiliki $H R$ yang mengalami peningkatan, sedangkan 4 responden yang memiliki hasil HR yang mengalami penurunan sebelum dan sesudah dilakukan perlakuan (intervensi) kegiatan kegiatan bermain meniup balon (ballon therapy) dari total 22 responden.

Hal tersebut karena sistem oksigenasi pada manusia yang terdiri atas paru dan sistem kardiovaskuler. Penyampaian tergantung pada jumlah oksigen yang masuk kedalam paru-paru (ventilasi), darah mengalir ke paru-paru dan jaringan

(perfusi), kecepatan difusi, serta kapasistas kandungan oksigen. Tiga hal yang mempengaruhi kapasitas darah untuk membawa oksigen adalah jumlah oksigen terlarut dalam plasma, jumlah

hemoglobin, dan kecendrungan hemoglobin untuk berikatan dengan oksigen, dimana dari hasil laboratorium responden pada rekam medik menunjukkan rata-rata kadar hemoglobin responden dengan nilai terendah adalah 9,9 Mg/dL dan hasil tertinggi adalah 12,8 $\mathrm{Mg} / \mathrm{dL}$ dimana rentang normal hemoglobin pada anak adalah $10-16 \mathrm{Mg} / \mathrm{dL}$.

Selain dari kadar hemoglobin dan suhu, Dehidrasi juga dapat di jadikan sebagai variabel confounding yang dapat

memepengaruhi status oksigenasi. Berdasarkan literatur yang menjelaskan bahwa hipovolemia atau kondisi seperti syok dan dehidrasi berat dapat

menyebabkan kehilangan cairan ekstraseluler dan mengurangi volume darah yang bersirkulasi, atau hipovolemia. Dengan kehilangan cairan yang signifikan, tubuh mencoba untuk beradaptasi dengan meningkatkan denyut jantung dan vasokontriksi perifer untuk meningkatakan volume darah yang kembali ke jantung dan sebaliknya meningkatkan curah jantung.

Penelitian yang serupa yang mendukung penelitian ini diantaranya adalah penelitian yang dilakukan oleh Sutini (2011). Menunjukkan bahwa aktivitas bermain meniup "tiupan lidah" memberikan pengaruh positif terhadap status oksigenasi Heart Rate anak usia prasekolah dengan pneumonia.

Pertumbuhan anak berhubungan erat dengan peningkatan percabangan dari bronkiolus perifer dan jumlah alveoli. Semakin anak bertambah tinggi maka semakin besar dan luas permukaan paruparu. Organ jantung semakin kuat dengan bertambah kuatnya otot jantung dalam memompakan darah ke seluruh tubuh yang sangat bermakna Webster dan Huether (1998) menjelaskan bahwa untuk mempertahankan status oksigenasi jaringan yang dapat dinilai melalui $\mathrm{SaO}_{2}$. Berdasarkan pendapat tersebut bahwa $\mathrm{SaO}_{2}$ erat hubungan dengan usia anak ${ }^{[5]}$

Hasil status oksigenasi Respiratory Rate (RR) didapatkan rata-rata $\mathrm{RR}$ responden mengalami peningkatan sebanyak 5 responden, 11 responden yang mengalami penurunan RR dan 6 responden yang memiliki hasil pengukuran $\mathrm{RR}$ yang menetap setelah diberikan kegiatan meniup balon (balloon therapy) dari total 22 responden. Berdasarkan teori menjelaskan bahwa ketika konsentrasi oksigen yang dihirup menurun maka kapasitas kandungan oksigen darah juga akan menurun. Pada fraksi konsentrasi oksigen yang dihirup $\left(\mathrm{FiO}_{2}\right)$ disebabkan 
oleh obstruksi saluran nafas atas atau bawah dapat membatasi penyampaian oksigen yang dihirup ke alveoli termasuk penyakit pneumonia.

Namun peneliti berasumsi bahwa, ketika anak melakukan aktivitas bermain meniup balon yang dianalogikan dengan Pursed Lips Breathing (PLB), jumlah penyerapan atau pengambilan oksigen (inspirasi) lebih besar dibandingkan bernafas secara normal, hal tersebut terjadi agar balon dapat mengembang dan terisi udara dari hembusan udara

ekspirasi. Sehingga memungkinkan oksigen yang masuk dalam jumlah besar dan dapat diserap oleh hemoglobin untuk di transportasikan ke alveoli. Inspirasi maksimal sistem pertukaran $\mathrm{O}_{2}$ dan $\mathrm{CO}_{2}$ Lancar akibat dari stimulasi Aplikasi bermain meniup balon.

Jumlah energi yang diperlukan untuk pernafasan tergantung pada kecepatan dan kedalaman pernafasan, kemudahan paru-paru untuk mengembang (penuh), dan ketahanan sistem pernafasan.

Penurunan pengembangan paru,
peningkatan
ketahanan pernafasan, dan ekspirasi aktif dengan menggunakan otot-otot pernafasan tambahan meningkatkan kerja pernafasan, menyebabkan peningkatan energi yang dikeluarkan. Tubuh akan meningkatakan laju metabolisme dan membutuhkan oksigen. Dimana hal tersebut merupakan salah satu faktor yang mempengaruhi oksigenasi yakni pada faktor fisiologis.

Selain dari faktor fisiologis dan faktor perkembangan yang telah dijelaskan sebelumnya pada karakteristik responden, beberapa faktor lain yang dapat

mempengaruhi status oksigenasi Respiratory Rate (RR) dalam hal ini adalah variabel Counfounding atau variabel perancu, diantaranya adalah Temperature (Suhu tubuh), khususnya pada kondisi Demam akibat laju metabolisme dalam tubuh. Dimana rata-rata suhu tubuh responden dari hasil observasi dan pencatatan pada buku rekam medik, responden memiliki suhu tubuh terendah adalah $36,0^{\circ} \mathrm{C}$ dan suhu tertinggi adalah $39,1^{\circ} \mathrm{C}$. Hal tersebut sebagai efek yang ditimbulkan akibat infeksi yang terjadi pada jaringan paru pada responden, yang merupakan manifestasi dari penyakit pneumonia. Dimana sebagian manusia dapat memenuhi kebutuhan oksigen yang meningkat dan tindak menunjukkan tandatanda kekurangan oksigen. Demam dapat menigkatkan kebutuhan jaringan akan oksigen dan sebagai hasilnya, produksi karbon dioksida juga meningkat.

Jika demam terus terjadi, laju metabolisme tetap tinggi dan tubuh mulai memakai simpanan protein, menyebabkan kerusakan otot dan mengurangi massa

otot. Otot-otot pernafasan seperti diagfragma dan otot-otot intrakostalis juga akan mengalami kerusakan. Akhirnya tubuh mencoba untuk beradaptasi terhadap peningkatan tingkat karbon dioksida dengan meningkatkan kecepatan dan kedalaman pernafasan. Kerja pernafasan klien menjadi meningkat, dan akhirnya klien menunjukkan tanda dan gejala hipoksemia. Klien dengan penyakit pulmonal memiliki risiko tinggi untuk mengalami hipoksemia.

Berdasarkan hasil observasi peneliti saat melakukan penelitian pada responden, kehilangan cairan lebih banyak ternjadi pada pasien demam yang mengeluarkan keringat yang berlebih (dari hasil metabolisme tubuh) ditambah suhu ruangan perawatan yang panas dan tidak memiliki pendingin ruangan yang juga dapat menjadi pemicu pengeluaran keringat yang berlebih.

Selain dari faktor tersebut, lama sakit (hari rawat) juga menjadi salah satu faktor yang mempengaruhi status oksigenasi, rata-rata lama sakit responden yang diberikan intervensi adalah 2-5 hari. Hal tersebut memungkinkan pasien atau responden telah dilakukan terapi dan pengobatan oleh petugas pelayanan kesehatan, sehingga pada saat diberikan perlakuan status oksigenasi Respiratory Rate responden sudah dalam ambang batas normal.

Hal ini sesuai dengan pernyataan dari hasil penelitian Miss Smita (2018), yaitu "Effect of Balloon Therapy vs. Bubble Therapy on LRTI among 3-12 Years Children", menunjukkan tidak ada perbedaan signifikan yang ditemukan pada tingkat respirasi pada responden ${ }^{[6]}$.

Menurut Sutini (2011) Semakin kuat meniup diharapkan semakin kuat pula silia bergerak untuk mendorong benda asing atau sekret keluar dari jalan nafas

sehingga pada akhirnya dapat memberikan dampak positif terhadap perubahan $\mathrm{RR}$, $\mathrm{HR}$ dan $\mathrm{SaO}_{2}$.

Hasil pengukuran status oksigenasi Saturasi Oksigen $\left(\mathrm{SaO}_{2}\right)$ dengan menggunakan alat Pulse Oksimetri diperoleh rata-rata $\mathrm{SaO}_{2}$ responden mengalami peningkatan saturasi oksigen sebanyak 21 responden dan sebanyak 1 
responden yang memiliki hasil pengukuran $\mathrm{SaO}_{2}$ yang menetap sebelum dan sesudah diberikan kegiatan meniup balon (balloon therapy) dari total 22 responden.

Berdasarkan beberapa menjelaskan bahwa Saturasi $\left(\mathrm{SaO}_{2}\right)$ adalah persentasi kadar hemoglobin yang berikatan dengan oksigen dalam arteri. Dimana hemoglobin yang merupakan suatu pembawa oksigen dan karbon dioksida, mentransportasikan lebih banyak oksigen (sekitar 97\%).

Molekul hemoglobin berikatan dengan oksigen membentuk oksihemoglobin, bentuk okshihemoglobin bersifat sangat reversibel, sehingga oksigen dan haemoglobin dapat memisahkan diri, dimana oksigen bebas kemudian masuk ke jaringan. Maka untuk melakukan pengukuran status oksigenasi khususnya $\mathrm{SaO}_{2}$ maka perlu menggukan sebuah alat salah salat yang digunakan adalah Pulse Oximetry.

Hasil penelitian ini didukung oleh penelitian Sreeletha A. (2016) yakni "Effect of balloon therapy v/s spirometry in promotion of respiratory function in children with respiratory infection"

mengatakan bahwa meniup balon atau

ballon therapy lebih efektif member pengaruh yang signifikan pada status oksigenasi saturasi oksigen serta mengurangi gejala pernafasan ${ }^{77]}$.

Berdasarkan hasil penelitian, teori pendukung dan hasil penelitian sebelumnya, maka peneliti berkesimpulan bahwa dengan pemberian aplikasi kegiatan bermain meniup balon (balloon therapy) pada anak, ternyata mampu memberikan peningkatan status oksigenasi khususnya pada Heart Rate

dan Saturasi Oksigen. Intervensi keperawatan dalam meningkatan status oksigenasi pada anak dengan pneumonia sangat penting dilakukan. Kegiatan bermain meniup balon (balloon therapy) ini merupakan analogi atau modifikasi intervensi dari teknik nafas dalam Purse Lips Breathing (PLB) dengan pendekatan atraumatic care dari aktivitas bermain yang mampu diterima oleh anak. Anak dapat mengeksplorasi kecemasan dan ketakutan saat sedang mengalami stress hospitalisasi dengan bermain. Dengan menerapkan kegiatan bermain meniup balon pada anak dengan pneumonia, oksigen atau $\mathrm{O}_{2}$ yang dihirup akan lebih besar dibanding bernafas secara normal dan memungkinkan hemoglobin dapat mengikat lebih banyak $\mathrm{O}_{2}$ untuk di

transportasikan ke alveoli. Hal tersebut terjadi agar balon yang ditiup oleh anak dapat mengembang secara sempurna dimana semakin banyak oksigen yang dihirup maka balon yang ditiup juga akan mengembang lebih besar, mengingat kegiatan tersebut sesuai pada usia prasekolah dimana perkembangan motorik halus pada anak telah berkembang secara baik.

\section{KESIMPULAN}

Dari hasil penelitian yang dilakukan di Rumah Sakit Tk.II Pelamonia tanggal 04 Juni sampai 04 Juli 2018 dengan jumlah responden sebanyak 22 responden, dapat disimpulkan bahwa terdapat pengaruh yang signifikan terhadap Heart Rate (RR) dan Saturasi Oksigen $\left(\mathrm{SaO}_{2}\right)$, sedangkan pada Heart Rate (HR) tidak terjadi pengaruh yang signifikan sebelum dan sesudah dilakukan kegiatan bermain meniup balon (balloon therapy) terhadap status oksigenasi anak usia 3-5 tahun denga pneumonia di Rumah Sakit Tk.II Pelamnia.

Hasil penelitian ini diharapkan dapat diterapkan dalam memberikan asuhan keperawatan pada anak yang mengalami gangguan status oksigenasi dengan menggunakan pendekatan atraumatic care.

\section{REFERENSI}

Irianto K. Ilmu Kesehatan Anak. Bandung: Alfabeta; 2014.

IDIAI. Menekan Pneumonia [Internet]. 2017 [dikutip 20 Maret 2018]. Diambil dari: (http//0.0.7.226/referensi internet/IDAl Menekan Pneumonia.htm Diakses situasi tanggal 20 Maret 2018)

Dinkes. Profil Kesehatan Provinsi Sulawesi Selatan. 2015.

UNICEF. Children: reducing mortality. Internet. 2017.

Sutini T. Pengaruh Aktivitas Bermain Meniup Tiupan Lidah Terhadap Status Oksigenasi Pada Anak Prasekolah Dengan Pneumonia Di Rumah Sakit Islam Jakarta. 2011;

Miss Smita Manjusha Das MGRN and MRP. Effect of Balloon Therapy vs. Bubble Therapy on LRTI Among 3-12 Years Children. Int $\mathrm{J}$ Heal Sci Reasearch. 2018; Vol 8(1 January 2018).

Sreeletha A. Effect of balloon therapy $\mathrm{v} / \mathrm{s}$ spirometry in promotion of respiratory function in children with respiratory infection. Int J Nurs Res Int. 2016;2 (1). 
